\title{
Discouraging Rivals: Managerial Rent-Seeking and Economic Inefficiencies
}

\author{
By Aaron S. Edlin and Joseph E. Stiglitz*
}

Managerial theories of the firm have a long and controversial history, beginning perhaps with Adolf A. Berle, Jr. and Gardiner C. Means's classic (1932) study. Such theories postulated that managers had considerable discretion running corporations and exercised it to pursue objectives other than maximizing shareholder market value.

Critics later denied that managers really have discretion, arguing that such behavior could not survive in equilibrium. Either management would be voted from office, the firm would be taken over, or the firm would go bankrupt in a competitive product market.

The more recent literature on information economics emasculated these criticisms. Managers are important to corporate decision-making because of their expertise and the information they acquire about the firm and its prospects. Yet the very information asymmetries that create a need for management also limit the discipline that the board of directors can impose on managers. At the same time, neither the shareholder-voting mechanism nor the takeover mechanism provides effective discipline.' Small shareholders free ride on the

\footnotetext{
* Edlin: Department of Economics, 549 Evans Hall, University of California, Berkeley, CA 94720; Stiglitz: Department of Economics, Stanford University, Stanford, CA 94305-6072, and Council of Economic Advisers, Washington, DC. This paper was originally prepared for a conference sponsored by the Center for Economic Policy Research, Stanford, May 1991. We thank the National Science Foundation and the Hoover Institution for financial support and Jeremy Bulow, Eric Emch, Kirsten Landeryou, Peter Klein, Jonathan Paul, Jeffrey Zwiebel, and the anonymous referees, for their comments. The views expressed are solely those of the authors and not necessarily of any organization with which they are or have been affiliated.

'The theoretical literature on takeovers includes Stiglitz $(1972,1975)$ and Sanford S. Grossman and Oliver D. Hart (1980). The empirical literature includes Michael Jensen (1988), David Scharfstein (1988), and Andrei Shleifer and Robert W. Vishny (1988). For discussions of
}

efforts of others, since it does not pay for them to obtain the costly information needed to exercise their proxy vote intelligently. Moreover, if a takeover will enhance the productivity of the firm, it will likewise enhance its market value, so small shareholders are better off holding onto their shares than tendering them. Takeovers can therefore be difficult when ownership is dispersed. Indeed, the theoretical arguments suggest that the takeover mechanism should be even less effective than it seems to be in practice. It has become more of a theoretical puzzle to explain the existence of managerial discipline than of managerial discretion. $^{2}$

These observations argue for a return to the viewpoint of the earlier managerial literature, which presumed that managers have discretion and asked how they will use it (see James G. March and Simon, 1958; Robin L. Marris, 1964; Oliver E. Williamson, 1964; Harvey Leibenstein, 1966). This paper continues that tradition, examining one route-namely, investment choice-by which managerial discretion affords managers the opportunity to obtain "rents" (payments in excess of their opportunity costs). We thereby expand on the theme of Shleifer and Vishny's (1989) insightful paper on "managerial entrenchment."

A somewhat earlier literature on incomplete contracts emphasized the investment consequences of rent-seeking. That literature explained how concern about opportunism can

the voting (or proxy) control mechanisms, see Stiglitz (1981), Jensen and Richard S. Ruback (1983), and Randall Morck et al. (1989).

${ }^{2}$ Early literature, such as Berle (1926), stressed the disciplinary role of banks (see also Stiglitz, 1985). More recently, organization theorists and some economists have emphasized social control mechanisms (attempts to make managers identify with the company, and adopt the "wellbeing" of the corporation as their own private goals). On this, see George A. Akerlof (1991) and Herbert A. Simon (1991). 
lead to underinvestment in such relationshipspecific investments such as a manager's investment in firm-specific human capital (see Aaron S. Edlin and Stefan Reichelstein [1993] for citations). We argue here for a broader view of the biases in managers' decisions: In general, managerial rent-seeking affects not only the level of investment, but also the form. ${ }^{3}$

Our basic hypothesis is simple: given the now well-established scope for managerial discretion, managers have an incentive to exercise that discretion to enhance their income. Any managerial contract is subject to renegotiation, and a manager's pay is the outcome of an often bewildering bargaining process between management, the board of directors, and rival management teams or takeover artists. Two critical factors in that bargaining process are the incumbent management's productivity relative to rivals and the wages that rivals demand. A manager may increase her compensation either by increasing her own productivity (the aspect generally stressed) or by decreasing the threat from rival managers. ${ }^{4}$ Shleifer and Vishny (1989) consider the latter possibility and show that a manager can increase her rents by choosing to invest in projects she can manage better than her rivals.

Here we explore a new avenue for entrenchment. The prototypical example of the Shleifer and Vishny (1989) effect is a secretary who becomes invaluable by rearranging a filing system to suit his own idiosyncratic search patterns. Yet we observe that managers often retain their jobs without making such investments; they are rehired even when they select assets for which their own idiosyncratic talents are not the best match. We suggest that these managers may preserve their jobs by investing in activities for which information asymmetries are particularly large (our arguments are

\footnotetext{
${ }^{3}$ See Edlin (1992) for the argument that the important distortions in the incomplete-contracts context are also in the form, not the level, of investment.

${ }^{4}$ Although the contexts differ, there is a strong similarity between our argument and Steven C. Salop and David T. Scheffman's $(1983,1987)$ analysis of the behavior of firms in imperfectly competitive markets. They argue that firms can enhance their profits not only by increasing their own productivity, but also by reducing the threat of rivals, (i.e., by raising rivals' costs).
}

in the same spirit as Laurie S. Bagwell and Josef Zechner [1993]). In our theory, managers invest to create these asymmetries, not to exploit their talents. They thus engage in a form of rent-seeking even less productive than that considered by Shleifer and Vishny (1989).

Our theory predicts, for example, that managers will overvalue acquisitions that promise potential, but not certain, synergies, since such acquisitions can bring rents to incumbent managers as long as they get earlier or more accurate signals than rivals of whether these synergies materialize. This argument suggests that the recent wave of acquisitions in the media and communications industries is a sensible entrenchment strategy, because the potential synergies are large, even if the expected synergies might not be.

Such possibilities become clearer as the paper unfolds. Section I sets up the framework for discouraging rivals. Section II analyzes how to discourage rivals who can observe investment levels. Section III considers discouraging rivals who cannot observe the mix of investment, and the final section outlines some implications of the analysis both for policy and empirical work.

\section{Discouraging Rivals: The Framework}

We present a three-stage model. In the first stage the manager chooses investments. In the second, the board of directors decides who will manage the firm's assets, and in the third, the manager manages the assets.

Managers choose investments to maximize the product of the probability that they are rehired in stage 2 and the rents they expect to accrue conditional upon being rehired:

$$
\max _{\left\{I_{1}, I_{2}\right\}}[E[\text { rents } \mid \text { incumbent rehired }]
$$

$$
\times \operatorname{Pr}\{\text { incumbent rehired }\}] \text {. }
$$

This formulation does not imply risk neutrality: instead, these rents are in units of utility and represent the difference between the utility the manager could get from outside opportunities (which we assume to be constant) and the utility from the stage- 2 contract, which is a function of the contract she negotiates and 
the effort she subsequently expends. We will soon be explicit about the sources of these rents, but at a general level, our argument is simply this: as the inherent ability of a manager's rivals falls, as the effort rival managers will exert falls, or as rivals demand higher wages to accept the position, then the incumbent manager will gather increased rents from contract negotiations, other things being equal.

Of course, some students of corporate culture may rebel at the image of a board of directors negotiating with the manager: The manager is often thought simply to name the terms of her contract, with the board providing the rubber stamp. Indeed, boards sometimes do approve contracts with incumbent managers that predictably leave the firm worse off than under rival management. Nonetheless, even those who take an extreme view of the agency problems involved in the board's representation of shareholder interests will concede that something limits what managers can successfully demand. We suggest that these limits ultimately stem from the threat of replacement by rivals. We therefore examine how managers can reduce this threat by discouraging rivals.

In our formulation, a firm's terminal, or stage-3 return, $R$, is a product of the effective quality of the manager and the prospects of the firm's ongoing projects:

$$
R=\left(C_{1}+C_{2}\right) q(e)
$$

where $q$ is the effective quality of the manager, which may depend upon effort $e$, and $C_{i}$ represents the "prospects"' in project $i, i$ $\in\{1,2\}$. The two projects can be thought of as a "short-run" and "long-run" project, or as two different activities run over the same time horizon. $C_{i}$ may represent the potential cash flows or underlying "capital" of project $i$. It is stochastically related to the firm's stage- 1 investment according to some risk $\theta_{i}$, which increases proportionately with investment:

$$
C_{i}=F_{i}\left(I_{i}\right)+\theta_{i}
$$

where

$$
\theta_{i} \sim \mathcal{N}\left(0, I_{i}^{2} \sigma_{i}^{2}\right), \quad i \in\{1,2\} .
$$

We consider two main cases: in the first, outsiders can observe the mix of investment in the two activities; in the second, they only observe total investment $I_{1}+I_{2}$. In both cases, the incumbent observes $C_{i}$ accurately, while rivals must try to infer $C_{i}$ from the signals $Y_{i}$, defined as

$$
Y_{i}=C_{i}+\varepsilon_{i}
$$

where

$$
\varepsilon_{i} \sim \mathcal{N}\left(0, I_{i}^{2} w_{i}^{2}\right), i \in\{1,2\}
$$

and where the $\varepsilon$ 's and $\theta$ 's are all independent.

The first-best mix of investment maximizes $E\left[C_{1}+C_{2}\right]$. Assuming an interior solution, optimal investments are some $I_{1}^{*}$ and $I_{2}^{*}$ such that $F_{1}^{\prime}\left(I_{1}^{*}\right)=F_{2}^{\prime}\left(I_{2}^{*}\right)$. The next two sections show, however, that these first-best investments do not solve the investment problem for a manager trying to entrench herself. The investment choices will be distorted regardless of whether the mix of investment she chooses is observable to outsiders or remains unobservable. In either case, the manager favors investments in which information is more quickly or fully revealed to her than to outsiders, although the reasons for the distortions differ somewhat between the two cases.

\section{Case 1: Observable Investment}

Rivals base their expectation of the firm's potential cash flows on their observations $Y_{1}$ and $Y_{2}$. This expectation is given by

$$
\begin{aligned}
E & {\left[C_{1}+C_{2} \mid Y_{1}, Y_{2}\right] } \\
& =\beta_{0}+\beta_{1} Y_{1}+\beta_{2} Y_{2}
\end{aligned}
$$

where

$$
\begin{gathered}
\beta_{i}=\frac{\sigma_{i}^{2}}{w_{i}^{2}+\sigma_{i}^{2}} \quad i \in\{1,2\} \\
\beta_{0}=\frac{w_{1}^{2}}{w_{1}^{2}+\sigma_{1}^{2}} F_{1}\left(I_{1}\right)+\frac{w_{2}^{2}}{w_{2}^{2}+\sigma_{2}^{2}} F_{2}\left(I_{2}\right) .
\end{gathered}
$$

We derive this expectation formula in the Appendix. Since in this section's analysis, 
outsiders can observe the investment mix, the intercept term $\beta_{0}$ is a function of the actual investments $I_{1}$ and $I_{2}$. This feature differs from Section III, which analyzes unobservable investment.

\section{A. Investing to Discourage Rivals' Efforts}

After the investments are chosen, the assets must be managed, either by the incumbent manager or by some rival. In either case, the manager chooses her effort level to maximize her expected utility given her information. The firm must provide the manager with some incentive to expend effort, and for simplicity we assume that the manager who is given responsibility for managing the assets has an incentive contract giving her a share in profits. ${ }^{5}$ Thus, if $W$ represents manager $j$ 's fixed wage income, $s$ her share of profits, $U$ her utility function, $p_{j} e$ her personal cost of expending effort $e$ ( $p_{j}$ is an index of her ability), and $\Phi$ her information set, the manager chooses effort to maximize

$$
E\left[U\left[W+s\left(C_{1}+C_{2}\right) q(e)-p_{j} e\right] \mid \Phi\right]
$$

Assuming constant absolute risk aversion, so that the certainty equivalent is linear in the mean and variance of wealth, ${ }^{6}$ the manager's problem is to maximize

$$
\begin{aligned}
W & +s q(e) E\left[\left(C_{1}+C_{2}\right) \mid \Phi\right] \\
& -k s^{2} q^{2}(e) \operatorname{Var}\left[\left(C_{1}+C_{2}\right) \mid \Phi\right]-p_{j} e
\end{aligned}
$$

where $\operatorname{Var}\left[\left(C_{1}+C_{2}\right) \mid \Phi\right]$ is the variance of $C_{1}+C_{2}$ conditional upon the manager's information $\Phi$ and where $k$ equals half of the degree of absolute risk aversion. We assume that effective worker quality $q(e)$ increases with effort. Effort is costly and so, all else

\footnotetext{
${ }^{5}$ For one justification of linear incentive schemes, see Bengt Holmstrom and Paul R. Milgrom (1987).

${ }^{6}$ We do not require all the structure of constant absolute risk aversion in order for Lemma 1 to hold and the subsequent analysis to be valid. In particular, the strong linearity is not important: it would be sufficient for our purposes that effort enter separably and that managers' utility be some increasing function of expected wealth and decreasing function of the variance of wealth.
}

equal, managers with a higher cost of effort $p_{j}$ exert less effort, and have lower effective quality. However, a manager's effort, and hence effective quality $q$, also depends upon her appraisal of a firm's prospects.

In our model, a rival who takes over a management role must decide her effort before learning the prospects $C_{1}+C_{2}$. This timing captures important features that we would neglect by assuming that rivals observe $C_{1}$ and $C_{2}$ before choosing effort. When the rival takes over, he will not be handed the keys to some safe containing the secret information " $C_{1}$ ", and " $C_{2}$." That would be a poor caricature of private information. Witness the fact that it took John Sculley four months to discover the desperate condition of Spectrum, and consider that such information is often less concrete than in that case. ${ }^{7}$ Relevant information can be quite diffuse, spread among many present and former officials of the firm, and revelation to the new management team is far from immediate. Thus, while our assumption that nothing new is learned after taking the helm is extreme, it neatly captures the fact that much of what was known to the predecessor remains unknown to new management.

We are now prepared to state a useful lemma.

LEMMA 1: Holding the cost of effort and other factors constant, an interior solution to manager $j$ 's effort choice problem $e^{* j}$ increases with $E\left[\left(C_{1}+C_{2}\right) \mid \Phi\right]$ and decreases with $\operatorname{Var}\left[\left(C_{1}+C_{2}\right) \mid \Phi\right]$.

\section{PROOF:}

The lemma follows from the form of the manager's objective function together with the fact that effective quality $q$ increases with effort. The cross derivative with respect to $q$ and $E\left[\left(C_{1}+C_{2}\right) \mid \Phi\right]$ is positive and with respect to $q$ and $\operatorname{Var}\left[\left(C_{1}+C_{2}\right) \mid \Phi\right]$ is negative, so Milgrom and Christina Shannon's (1994) Monotone Selection Theorem implies that the solution to manager $j$ 's effort-choice problem is weakly increasing in $E\left[\left(C_{1}+C_{2}\right) \mid \Phi\right]$ and weakly decreasing in $\operatorname{Var}\left[\left(C_{1}+C_{2}\right) \mid \Phi\right]$.

\footnotetext{
${ }^{7}$ See Jonathan Weber (1994) for a description of the Sculley-Spectrum saga.
} 
These results are strict whenever $e^{* j}$ is interior as assumed, because then if first-order conditions hold for one expectation or variance, they fail for higher ones.

We now proceed to examine how current management's actions can poison the applicant pool for the manager's job by lowering the effectiveness of rival management. The current manager can reduce rivals' efforts by increasing their perceived uncertainty about the firm's prospects. The incumbent's effort and hence effective quality rises relative to rivals with an increase in

$$
\begin{aligned}
& \operatorname{Var}\left[\left(C_{1}+C_{2}\right) \mid \Phi_{\text {riv }}\right] \\
& -\operatorname{Var}\left[\left(C_{1}+C_{2}\right) \mid \Phi_{\text {inc }}\right]
\end{aligned}
$$

where $\Phi_{\text {riv }}$ denotes the information of the rivals and $\Phi_{\text {inc }}$ denotes that of the incumbent.

Recall that the incumbent observes $C_{1}+C_{2}$, so $\operatorname{Var}\left[\left(C_{1}+C_{2}\right) \mid \Phi_{\text {inc }}\right]=0$. In contrast, rival management teams can only infer $C_{1}+C_{2}$ from the noisy signals $Y_{1}$ and $Y_{2}$. The Appendix shows that

$$
\begin{aligned}
& \operatorname{Var}\left(C_{1}+C_{2} \mid Y_{1}, Y_{2}\right) \\
& =\frac{\sigma_{1}^{2} w_{1}^{2} I_{1}^{2}}{\sigma_{1}^{2}+w_{1}^{2}}+\frac{\sigma_{2}^{2} w_{2}^{2} I_{2}^{2}}{\sigma_{2}^{2}+w_{2}^{2}} .
\end{aligned}
$$

Equation (8) reveals that the manager will favor highly noisy investments (high $w^{2}$ for any given $\sigma^{2}$ ): such investments decrease the effectiveness of outside managers by increasing expression (7). ${ }^{8}$ These gains from increasing noise are larger for higher underlying risks, and in the extreme case where $\sigma^{2}=0, w^{2}$ becomes irrelevant because the potential cash flows are fully determined by the observable investment levels. Finally, in choosing among projects with similar risk $\left(\sigma^{2}\right)$ and noise

\footnotetext{
${ }^{8}$ Notice that such a result is quite different from the more standard asset-substitution result of Jensen and William H. Meckling (1976 section 4.1). They argue that equity-holders will be biased to invest in high-risk assets since limited liability cuts off their downside risk. The noise $w^{2}$ should be distinguished from the fundamental risk $\sigma^{2}$.
}

for outside investors $\left(w^{2}\right)$, incumbents can decrease the effectiveness of rivals by concentrating their investments, because of the convexity of $I^{2}$. Accordingly, rent-seeking may cause overspecialization.

\section{B. Discouraging Applicants}

In addition to reducing the effective quality of the rivals, the incumbent manager's investment choices can raise rivals' wage demands. For manager $j$, with reservation utility level $r(j)$, to be willing to work for the firm, she must be offered a high enough wage that

$$
\begin{gathered}
W+s q\left(e^{* j}\right) E\left[\left(C_{1}+C_{2}\right) \mid \Phi\right]-p_{j} e^{* j} \\
>r(j)+k s^{2} q^{2} \operatorname{Var}\left(C_{1}+C_{2} \mid \Phi\right) .
\end{gathered}
$$

The right-hand side represents the familiar fact that the manager must be compensated both for her reservation price $r(j)$, and for the risk from the incentive plan given by $s$. When $\operatorname{Var}\left(C_{1}+C_{2} \mid \Phi_{\text {riv }}\right)$ increases, any given compensation package will fall below the reservation wage of some rivals. These managers choose not to apply, weakening the pool of rivals and increasing the chance that the incumbent is rehired.

\section{Increasing Rivals' Winner's Curse}

A third reason for a manager to invest in noisy projects is that such projects create a winner's curse effect. This effect further discourages applicants from "applying" and makes those who do apply demand higher offsetting compensation. Recall that the incumbent knows $C_{1}+C_{2}$, so that

$$
E\left(C_{1}+C_{2} \mid \Phi_{\mathrm{inc}}\right)=C_{1}+C_{2} .
$$

The rival manager does not know $C_{1}+C_{2}$, but knows that, if he were to observe a value of $Y_{1}$ and $Y_{2}$ such that his expectation of $C_{1}+C_{2}$ is the same as that of the incumbent, the board of directors would likely stick with the incumbent for the two reasons already discussed: (a) all else equal, incumbents work harder because the returns to their effort is more certain; and (b) incumbents are willing to accept the 
job at lower compensation since their perceived risk is smaller.

Thus, the incumbent will be able to cut a deal with the board of directors, beating out rival management offers unless (a) the incumbent has a very high reservation wage relative to rivals; (b) the board of directors' estimate of the rival's ability is high relative to the incumbent; or (c) the rival has seriously overestimated the value of the project ( $\varepsilon$ is high). Holding the first two factors constant, the rival manager knows he gets the job only when his signal is overly optimistic. He takes this into account in forming his expectations. (Consider the Wall Street Journal headline after John Akers left quietly: "Akers Quits at IBM"' together with the sub-headline, "But Who'd Want This Job?' [Michael W. Miller and Laurence Hooper, 1993]). ${ }^{9}$

In determining whether to apply, the rival manager in fact considers

$$
E\left[C_{1}+C_{2} \mid Y_{1}, Y_{2} \text {, incumbent not rehired }\right]
$$

instead of

$$
E\left[C_{1}+C_{2} \mid Y_{1}, Y_{2}\right]
$$

This winner's curse further reduces rivals' efforts and their willingness to accept a job, ${ }^{10}$ since as explained above,

$$
\begin{aligned}
& E\left[C_{1}+C_{2} \mid Y_{1}, Y_{2}, \text { incumbent not rehired }\right] \\
& \quad<E\left[C_{1}+C_{2} \mid Y_{1}, Y_{2}\right] .
\end{aligned}
$$

Assume that the incumbent manager's rents conditional upon being rehired increase linearly with the wedge,

$$
C_{1}+C_{2}-E\left[C_{1}+C_{2} \mid Y_{1}, Y_{2},\right.
$$

incumbent not rehired]

\footnotetext{
${ }^{9}$ Miller and Hooper (1993) report that "In the end, International Business Machines Corp. had unraveled so badly that there wasn't any need for a fractious boardroom coup."

${ }^{10}$ Rivals' management teams' estimates of the relevant variances may also have to be altered to take into account the winner's curse phenomenon, but we assume that the truncation leaves the risk-ordering of investments the same.
}

and the conditional variance,

$$
\begin{aligned}
\operatorname{Var}\left[C_{1}\right. & +C_{2} \mid Y_{1}, Y_{2}, \\
& \text { incumbent not rehired }] .
\end{aligned}
$$

Recall that the incumbent manager's investment problem is

$$
\begin{aligned}
\max _{\left\{I_{1}, I_{2}\right\}}[E[\text { rents } \mid \text { incumbent rehired }] \\
\times \operatorname{Pr}\{\text { incumbent rehired }\}] .
\end{aligned}
$$

Our analysis indicates that the return to a noisy investment (one with a high value of $w^{2}$ for any given $\sigma^{2}$ ) is larger than the return to one for which $Y$ is a good signal of the project's potential cash flows, for three distinct reasons: (a) the noise directly discourages rivals' efforts and thus makes rivals less attractive as managers; (b) the noise directly discourages rivals from applying (and makes them insist on higher compensation ), thus making them a less viable threat; and (c) the noise increases the asymmetry of information and accordingly the winner's curse effect.

Consider the extreme case in which rivals can perfectly observe project 1 but only observe project 2 via a noisy signal. If the fundamentals of the two projects are sufficiently close, we would expect project 2 to be chosen even though shareholders would favor investment in project 1 . By investing in the noisy project, managers raise both the probability of being rehired and the average rents they obtain when they are rehired. Section IV argues that some of the recent acquisitions in preparation for the nascent information age probably represent such entrenchment activities.

\section{Extensions: Multidimensional Effort}

A similar analysis could be done to explore a model in which, instead of choosing investment at stage 1, a manager chooses how to allocate his own effort between the projects. Jonathan M. Paul (1992) studied that problem in considering the efficiency of stock-based compensation. In terms of our notation, he found that the manager's effort would be increasing in $\sigma_{i}^{2}$ and decreasing in $w_{i}^{2}$. Our con- 
clusions for such an analysis would differ from his because, unlike Paul (1992), we imagine that the managerial contract is negotiated or renegotiated after these decisions. Noise (high $w_{i}^{2}$ ) may discourage rivals and put the incumbent in a better position to extract rent in these renegotiations. In contrast, Paul's (1992) effects would dominate if the contract were preset to include stock-based compensation, and could not be renegotiated, since noisy projects have the drawback of having little influence on the stock price, as Paul observes.

\section{Case 2: Unobservable Investment}

We assume that the manager has a budget $\bar{I}$ to allocate between projects 1 and 2 , and that although the financial statements reveal the total investment, they do not disclose the mix of investment dollars between the two projects. Rivals must therefore base their projections of the firm's prospects upon the equilibrium investment mix, together with the observable signals $Y_{1}$ and $Y_{2}$. The expected value of these prospects conditional upon the observations $Y_{1}$ and $Y_{2}$ are derived in the Appendix and given by

$$
E\left[C_{1}+C_{2} \mid Y_{1}, Y_{2}\right]=\beta_{0}+\beta_{1} Y_{1}+\beta_{2} Y_{2}
$$

where

$$
\begin{gathered}
\beta_{i}=\sigma_{i}^{2} /\left(\sigma_{i}^{2}+w_{i}^{2}\right) \quad i \in\{1,2\} \\
\beta_{0}=\frac{w_{1}^{2}}{w_{1}^{2}+\sigma_{1}^{2}} F_{1}\left(\hat{I}_{1}\right)+\frac{w_{2}^{2}}{w_{2}^{2}+\sigma_{2}^{2}} F_{2}\left(\hat{I}_{2}\right) .
\end{gathered}
$$

Altering the mix of investment alters $Y_{1}$ and $Y_{2}$, but since rivals do not observe deviations, they will not change the rule, given in equation (17), by which they form expectations. The intercept term here is a function of the equilibrium investments $\hat{I}_{1}$ and $\hat{I}_{2}$, unlike in equation (4), where actual investments are observed.

The incumbent can reduce the effectiveness of rivals by raising $E\left[C_{1}+C_{2} \mid \Phi_{\text {inc }}\right]-E\left[C_{1}+\right.$ $\left.C_{2} \mid \Phi_{\text {riv }}\right]$. We can see that she will not generally choose the first-best investments $I_{1}^{*}$ and $I_{2}^{*}$, because she would benefit from shifting some investment into the noisier project with the higher $w^{2} / \sigma^{2}$ and lower coefficient $\beta$. Such a shift increases the wedge $C_{1}+C_{2}-E\left[C_{1}+\right.$ $\left.C_{2} \mid Y_{1}, Y_{2}\right]:{ }^{11}$ To see this, observe that as a first-order approximation for small shifts in investment from $I_{1}^{*}$ and $I_{2}^{*}$ into the noisier project, for any given realization of $\varepsilon_{i}$ and $\theta_{i}$, $E\left[C_{1}+C_{2} \mid Y_{1}, Y_{2}\right]$ falls, while $C_{1}+C_{2}$ remains constant, since $F_{1}^{\prime}\left(I_{1}^{*}\right)=F_{2}^{\prime}\left(I_{2}^{*}\right)$.

Shifting investment to noisier projects reduces rivals' effective quality by reducing their optimal effort. A winner's curse problem, analogous to the one in the previous section, exacerbates this effect. In fact, all investment might potentially be in the noisier project in equilibrium. With sufficiently diminishing real returns, however, it will eventually no longer pay the incumbent to create noise, for, when returns are lower in the noisy asset, shifting investment lowers $C_{1}+C_{2}$ to a first-order approximation, just as it lowers $E\left[C_{1}+C_{2} \mid Y_{1}\right.$, $Y_{2}$ ]. Lowering $C_{1}+C_{2}$ lowers the incumbent's effort under any given incentive contract, making her a less desirable manager. Moreover, to the extent that the manager also places weight on $C_{1}+C_{2}$ in her decision problem (perhaps because she initially holds stock options ), lowering $C_{1}+C_{2}$ is directly undesirable.

We should finally observe that since rivals cannot observe the investment mix here, the incumbent cannot affect $\operatorname{Var}\left[C_{1}+C_{2} \mid Y_{1}, Y_{2}\right]$ as she could in the previous section; in this section $\operatorname{Var}\left[C_{1}+C_{2} \mid Y_{1}, Y_{2}\right]$ is determined by the equilibrium investment levels.

\section{Implications}

We conclude with some implications and interpretations of our analysis, asking four questions:

\footnotetext{
"With full knowledge of her investment level, the incumbent manager forms expectations about what outsiders' uninformed expectations will be. The incumbent's expectations might be written $E_{\mathrm{in}}\left[E_{\text {out }}\left(C_{1}+C_{2} \mid Y_{1}, Y_{2}\right) \mid I_{1}\right.$, $\left.I_{2}\right]$, and it is important to realize that it is an equilibrium condition that at the equilibrium investment levels, $\hat{I}_{1}, \hat{I}_{2}$, $E_{\text {in }}\left[E_{\text {oul }}\left(C_{1}+C_{2} \mid Y_{1}, Y_{2}\right) \mid \hat{I}_{1}, \hat{I}_{2}\right]=E_{\text {in }}\left[\left(C_{1}+C_{2}\right) \mid \hat{I}_{1}, \hat{I}_{2}\right]$. Because of the information difference of the two expectation operators, this equality would not hold "out of equilibrium' if the incumbent reallocated investment to try to create a wedge to get rents. This equality is a condition reflecting consistent or rational expectations.
} 
(i) Does this model explain management biases toward excessive growth such as those observed by Gordon Donaldson. (1984 pp. 36-42)?

In our view, managers' rents are associated with investing in noisy projects. If a firm never invested in new projects but simply maintained old assets, its manager would derive little rent, since past project returns would provide good information about asset values.

Indiscriminate growth will not, however, help management. For instance, replicating established ventures of known value does not benefit management. Growth increases a manager's rents in our model when returns are uncertain and when this uncertainty is resolved sooner for insiders than for outsiders. We think it a fair generalization that in new and emerging enterprises both $\sigma^{2}$ and $w^{2}$ are quite high, so we should look at these investments for evidence of entrenchment activities. The model can thus help explain biases toward growth, supplementing more traditional explanations of "empire building."

This bias toward innovative activities is not all bad. A bias toward innovation and expenditures on $R \& D$ may countervail tendencies toward excessive conservatism, tendencies such as managerial myopia, ${ }^{12}$ or the fact that managers tend to be more risk-averse than their typically better-diversified shareholders.

(ii) What implications does the theory have concerning the efficiency of corporate acquisitions and divestitures?

Traditional takeover theory argued that 1980's-style restructurings are necessarily efficiency-enhancing, since in each case, assets are sold to the manager or management team that can most effectively employ them, as evidenced by the price the winning bidder is willing to pay. Our analysis of information asymmetries enriches our understanding of the patterns of divestiture and acquisition and ex-

\footnotetext{
${ }^{12}$ See Paul (1991) for a short survey of the literature on myopia and for an instructive theory of why managers concentrate on immediate returns to maximize stockmarket value in a noisy world.
}

plains how inefficiencies can arise. If scant rents are associated with "mature" or wellestablished enterprises, it pays to spin-off such assets to owner-managers (who maximize value). The nonowner managers can use the proceeds to purchase assets whose value is hard for rivals to ascertain. Thus, in an auction for an asset (such as the recent bidding by QVC and Viacom for Paramount), what any manager is willing to pay depends not only on what the firm can extract from the asset, but on the rents she can derive from controlling it. These rents are likely to be larger if she can quickly alter the asset to make its market value more uncertain to outsiders. Thus, the "managerial" value of an asset may differ across firms; and the asset will be sold to the firm with the highest managerial value, not necessarily the one with the highest expected value of returns.

Managerial rents may be quite high for acquisitions that have great potential synergies with a firm's existing assets. Because the returns are supposed to materialize from synergies, they cannot be well established by studying the past results of the target firm. Only time can reveal the returns. Moreover, returns will likely be revealed much sooner to incumbents than to rivals.

The recent wave of acquisitions in the communications, computer, and entertainment industries may promote entrenchment. ${ }^{13}$ Managers are seeking long-horizon synergies in what they hope are the key information technologies of the next century. Such acquisitions have significant upside potential, but the downside may be as important to management as the upside. It is the uncertainty inherent to "potential" that creates rents, and as long as potential remains and inside managers see realizations before outsiders, incumbents may expect personal prosperity. Such assets are wise acquisitions for management, even if expected returns are not impressive. In contrast, nonsynergistic acquisitions, such as

\footnotetext{
${ }^{13}$ Examples include the Time-Warner merger, the acquisition of Paramount by Viacom, and the acquisitions of McCaw Cellular Communications by AT\&T. See Wall Street Journal (1994) for a discussion of the new merger wave.
} 
typified the formation of diversified conglomerates in the 1960's and 1970's, are not particularly valuable for entrenchment; they invite the sorts of takeovers and spin-offs that dominated the 1980's.

(iii) What can be done to combat or limit the rent-seeking we discuss?

First, by being aware of the natural potential biases in managerial behavior, the board of directors or shareholders can hope to uncover and stop the most flagrant instances of biased investment behavior. One recent example might be the efforts of two large QVC shareholders, Liberty Media and Comcast, to derail Barry Diller's attempted acquisition of CBS (see Chicago Tribune, 1994). A major quandary firms face, however, is that many investments that increase profits also increase managerial rents. For instance, profits can be high in new enterprises, but the barriers which serve to enhance firm profits may equally enhance managerial rents (see Benjamin E. Hermalin [1992] for a different view).

Second, the board may seek a way to prevent renegotiation of wages; it might "constitutionalize" the CEO's pay in corporate bylaws. Such an approach, however, has drawbacks: the inertial staying power of some bylaws may itself prove costly (the hazards of inflexibility are well illustrated by the American Tobacco Co.), ${ }^{14}$ and some states have acted to limit compensation schemes in bylaws. ${ }^{15}$ Perhaps a better way to limit (though not eliminate) the rent-seeking we analyze is the common plan to cope with other agency problems: at the expense of inefficient riskbearing, boards may require high (initial) stock ownership by management.

\footnotetext{
${ }^{14}$ In 1912, the shareholders of the American Tobacco Co. adopted a bylaw granting the president a bonus equal to 2.5 percent of net profits, with 1.5 percent going to each vice president. Twenty-eight years later, in 1930, this bylaw yielded the president an $\$ 840,000$ bonus! The minority shareholders can perhaps be excused their incivility for suggesting in Rogers v. Hill (289 U.S. 582, 1933), that such a payment constituted waste.

${ }^{15}$ Consider North Carolina Business Corporation Act $\$ 16(3)$ (1973): "No bylaw authorizing compensation of officers measured by the amount of a corporation's income
}

A third approach is for either boards or the government to require more stringent and detailed accounting and reporting. For instance, if reports identify the mix of investment, the distortions in Section III are eliminated. Furthermore, all the distortions we identify can be reduced to the extent that managers are required to report inside information faster and more accurately.

We recognize that it is in the nature of private information that calls for revelation are easier made than effectuated. Nonetheless, reporting requirements can have an effect. Few can doubt that because of the U.S. Securities Act of 1933 and the Securities Exchange Act of 1934, important information is public that would otherwise remain private. (Compare the information available about publicly traded companies in the United States with that available in nations that do not have, or do not enforce, such legislation.)

(iv) Finally, what empirical questions does our research open?

Our paper raises a number of empirical questions, most of which will require ingenuity to answer. In principle, one might test the predictions of the model if one were first willing to take a stand on what kinds of investments have returns known better to incumbents than rivals. One could then try to determine whether the marginal return tends to be lower for such investments than for those with returns that are more equally observable to insiders and outsiders. Such a result would imply that managers favor noisy investments and invest beyond the point where returns are equated. Since other papers (e.g., Paul, 1991, 1992) predict that managers who maximize shareholder value will shy away from noisy investments, empirical results would be helpful for understanding managerial objectives.

It would also be valuable to investigate how investment patterns have responded to changes in reporting requirements by the Financial Accounting Standards Board (FASB) and by regulatory bodies such as the Securities

or volume of business shall be valid after five years from its adoption unless renewed by the vote of the holders of a majority of the outstanding shares regardless of limitation on voting rights." 
and Exchange Commission (SEC). Significant responses might indicate that managers do, in fact, exploit information asymmetries when they are allowed.

\section{APPENDIX}

We first prove a simple statistical lemma necessary to derive the conditional expectations $E\left[C_{1}+C_{2} \mid Y_{1}, Y_{2}\right]$ and variances $\operatorname{Var}\left[C_{1}+C_{2} \mid Y_{1}, Y_{2}\right]$ given in the paper.

LEMMA A1: If $x$ and $y$ are independent normal variables and $x \sim \mathcal{N}\left(0, \sigma^{2}\right)$ and $y \sim \mathcal{N}\left(0, w^{2}\right)$, then the distribution of $x$ given that $x+y=s$ is

$$
\mathcal{N}\left(s \frac{\sigma^{2}}{\sigma^{2}+w^{2}}, \frac{\sigma^{2} w^{2}}{\sigma^{2}+w^{2}}\right) \text {. }
$$

\section{PROOF:}

The conditional density of $x$ can be written

$$
\begin{aligned}
& f(x \mid x+y=s)=\frac{f(x, x+y=s)}{f(x+y)} \\
& =\frac{\frac{1}{2 \pi \sigma w} \exp \left(-\frac{x^{2}}{2 \sigma^{2}}\right) \exp \left(-\frac{(s-x)^{2}}{2 w^{2}}\right)}{\frac{1}{\sqrt{2 \pi} \sqrt{\sigma^{2}+w^{2}}} \exp \left(\frac{-s^{2}}{2\left(\sigma^{2}+w^{2}\right)}\right)} \\
& =\frac{\sqrt{\sigma^{2}+w^{2}}}{\sqrt{2 \pi} \sigma w} \exp \left[\frac{-x^{2}\left(\sigma^{2}+w^{2}\right)}{2 \sigma^{2} w^{2}}\right. \\
& \left.+\frac{x s}{w^{2}}-\frac{s^{2}}{2 w^{2}}+\frac{s^{2}}{2\left(\sigma^{2}+w^{2}\right)}\right] \\
& =\frac{\sqrt{\sigma^{2}+w^{2}}}{\sqrt{2 \pi} \sigma w} \exp \left[-\frac{\sigma^{2}+w^{2}}{2 \sigma^{2} w^{2}}\right. \\
& \left.\quad \times\left(x-s \frac{\sigma^{2}}{\sigma^{2}+w^{2}}\right)^{2}\right] .
\end{aligned}
$$

Thus, the distribution of $x$ given that $x+y=s$ is

$$
\mathcal{N}\left(s \frac{\sigma^{2}}{\sigma^{2}+w^{2}}, \frac{\sigma^{2} w^{2}}{\sigma^{2}+w^{2}}\right)
$$

We can use Lemma $A l$ to find $E\left[C_{1}+\right.$ $\left.C_{2} \mid Y_{1}, Y_{2}\right]$ and $\operatorname{Var}\left[C_{1}+C_{2} \mid Y_{1}, Y_{2}\right]$. Since the investment levels are known,

$$
\begin{aligned}
& E\left[C_{1}+C_{2} \mid Y_{1}, Y_{2}\right]=F_{1}\left(I_{1}\right) \\
& \quad+F_{2}\left(I_{2}\right)+E\left[\theta_{1} \mid \varepsilon_{1}+\theta_{1}=Y_{1}-F_{1}\left(I_{1}\right)\right] \\
& \quad+E\left[\theta_{2} \mid \varepsilon_{2}+\theta_{2}=Y_{2}-F_{2}\left(I_{2}\right)\right]
\end{aligned}
$$

which by Lemma A1 equals

$$
\begin{aligned}
& F_{1}\left(I_{1}\right)+F_{2}\left(I_{2}\right)+\beta_{1}\left(Y_{1}-F_{1}\left(I_{1}\right)\right) \\
& \quad+\beta_{2}\left(Y_{2}-F_{2}\left(I_{2}\right)\right)
\end{aligned}
$$

where

$$
\beta_{i}=\frac{\sigma_{i}^{2} I_{i}^{2}}{\left(\sigma_{i}^{2}+w_{i}^{2}\right) I_{i}^{2}}=\frac{\sigma_{i}^{2}}{\sigma_{i}^{2}+w_{i}^{2}} .
$$

Choosing $\beta_{0}=F_{1}\left(I_{1}\right)\left[1-\beta_{1}\right]+F_{2}\left(I_{2}\right)[1-$ $\left.\beta_{2}\right]$, we get the formula in the text for $E\left[C_{1}+\right.$ $\left.C_{2} \mid Y_{1}, Y_{2}\right]$. It also follows that

$$
\begin{aligned}
& \operatorname{Var}\left(C_{1}+C_{2} \mid Y_{1}, Y_{2}\right) \\
& =\operatorname{Var}\left[\theta_{1} \mid \varepsilon_{1}+\theta_{1}=Y_{1}-F_{1}\left(I_{1}\right)\right] \\
& \quad+\operatorname{Var}\left[\theta_{2} \mid \varepsilon_{2}+\theta_{2}=Y_{2}-F_{2}\left(I_{2}\right)\right] .
\end{aligned}
$$

By Lemma A1, this equals half the sum of the harmonic means of $I_{1}^{2} \sigma_{1}^{2}$ and $I_{1}^{2} w_{1}^{2}$ and of $I_{2}^{2} \sigma_{2}^{2}$ and $I_{2}^{2} w_{2}^{2}$, as claimed in the text:

$$
\frac{I_{1}^{2} \sigma_{1}^{2} w_{1}^{2}}{\sigma_{1}^{2}+w_{1}^{2}}+\frac{I_{2}^{2} \sigma_{2}^{2} w_{2}^{2}}{\sigma_{2}^{2}+w_{2}^{2}}
$$

\section{REFERENCES}

Akerlof, George A. "Procrastination and Obedience." American Economic Review, May 1991 (Papers and Proceedings), 8I(2), pp. 1-19.

Bagwell, Laurie S. and Zechner, Josef. "Influence Costs and Capital Structure." Journal of Finance, July 1993, 48(3), pp. 9751008.

Berle, Adolf A., Jr. "Non-voting Stock and Bankers' Control." Harvard Law Review, April 1926, 39(6), pp. 673-93. 
Berle, Adolf A., Jr. and Means, Gardiner C. The modern corporation and private property. New York: Macmillan, 1932.

Chicago Tribune. "QVC Accepts Sweetened Takeovers." Business Section, 5 August 1994, p. 3.

Donaldson, Gordon. Managing corporate wealth: The operation of a comprehensive financial goals system. New York: Praeger, 1984.

Edlin, Aaron S. "Specific Investments, Holdups and the Efficiency of Contract Remedies." Unpublished manuscript, Stanford University, 1992.

Edlin, Aaron S. and Reichelstein, Stefan. "Holdups, Standard Breach Remedies, and Optimal Investment.' IBER Working Paper, University of California, Berkeley, 1993; American Economic Review (forthcoming).

Grossman, Sanford J. and Hart, Oliver D. “"Takeover Bids, the Free-Rider Problem, and the Theory of the Corporation." Bell Journal of Economics, Spring 1980, 11(1), pp. 4264.

Hermalin, Benjamin E. "The Effects of Competition on Executive Behavior." Rand Journal of Economics, Autumn 1992, 23(3), pp. 360-65.

Holmstrom, Bengt and Milgrom, Paul R. “'Aggregation and Linearity in the Provision of Intertemporal Incentives." Econometrica, March 1987, 55(2), pp. 303-28.

Jensen, Michael C. "Takeovers: Their Causes and Consequences.' Journal of Economic Perspectives, Winter 1988, 2(1), pp. 2148.

Jensen, Michael $C$. and Meckling, William $H$. "Theory of the Firm: Managerial Behavior, Agency Costs and Ownership Structure." Journal of Financial Economics, October 1976, 3(4), pp. 305-60.

Jensen, Michael C. and Ruback, Richard S. "The Market for Corporate Control: The Scientific Evidence." Journal of Financial Economics, April 1983, 11(1-4), pp. 5-50.

Leibenstein, Harvey. "Allocative Efficiency vs. 'X-Efficiency'.' American Economic Review, June 1966, 56(3), pp. 392-415.

March, James G. and Simon, Herbert A. Organizations. New York: Wiley, 1958.
Marris, Robin L. The economic theory of managerial capitalism. Glencoe, IL: Free Press, 1964.

Milgrom, Paul R. and Shannon, Chris. "Monotone Comparative Statics." Econometrica, January 1994, 62 (1), pp. 157-80.

Miller, Michael W. and Hooper, Laurence. "Akers Quits at IBM Under Heavy Pressure; Dividend Is Slashed. Outsiders Will Lead Search for New Chief Executive To Be a 'Change-Master.' But Who'd Want This Job?' Wall Street Journal, 27 January 1993, p. A1.

Morck, Randall; Shleifer, Andrei and Vishny, Robert W. "Alternative Mechanisms for Corporate Control." American Economic Review, September 1989, 79(4), pp. 84252.

Paul, Jonathan M. "Managerial Myopia and the Observability of Future Cash Flows.' Unpublished manuscript, University of Michigan, 1991.

"On the Efficiency of Stock-Based Compensation." Review of Financial Studies, 1992, 5(3), pp. 471-502.

Salop, Steven C. and Scheffman, David T. " Raising Rivals' Costs.' American Economic Review, May 1983 (Papers and Proceedings), 73(2), pp. 267-71. . "Cost-Raising Strategies." Journal of Industrial Economics, September 1987, 36(1), pp. 19-34.

Scharfstein, David. "The Disciplinary Role of Takeovers." Review of Economic Studies, April 1988, 55(2), pp. 185-200.

Shleifer, Andrei and Vishny, Robert W. "Value Maximization and the Acquisition Process." Journal of Economic Perspectives, Winter 1988, 2(1), pp. 7-20.

"Management Entrenchment: The Case of Manager-Specific Investments." Journal of Financial Economics, November 1989, 25(1), pp. 123-39.

Simon, Herbert A. "Organizations and Markets." Journal of Economic Perspectives, Spring 1991, 5(2), pp. 25-44.

Stiglitz, Joseph E. "Some Aspects of the Pure Theory of Corporate Finance: Bankruptcies and Takeovers." Bell Journal of Economics, Autumn 1972, 3(2), pp. 458-82. " Information and Economic Analysis," in Michael Parkin and Avelino R. 
Nobay, eds., Current economic problems. Cambridge: Cambridge University Press, 1975, pp. 27-52.

. "Ownership, Control, and Efficient

Markets: Some Paradoxes in the Theory of Capital Markets," in Kenneth D. Boyer and William G. Shepherd, eds., Economic regulation: Essays in honor of James R. Nelson. East Lansing, MI: Institute of Public Utilities, Michigan State University, 1981, pp. 311-41. "Credit Markets and the Control of Capital.' Journal of Money, Banking, and Credit, May 1985, 17(1), pp. 13352.

Wall Street Journal. "Big is Back in Style as Corporate America Deals, Buys, and Merges." Western Edition, 4 August 1994, p. Al.

Weber, Jonathan. "Saga of Apple's Ex-Chief Takes an Unusual Turn." Los Angeles Times, Home Edition, 8 February 1994, p. Al.

Williamson, Oliver $\mathbf{E}$. The economics of discretionary behavior: Managerial objectives in $a$ theory of the firm. Englewood Cliffs, NJ: Prentice-Hall, 1964. 
Copyright of American Economic Review is the property of American Economic Association and its content may not be copied or emailed to multiple sites or posted to a listserv without the copyright holder's express written permission. However, users may print, download, or email articles for individual use. 